\title{
Evaluasi Usability pada Learning Management System Berbasis Smartphone
}

\author{
Raisa Adila ${ }^{1}$, Danu Hadi Syaifullah ${ }^{2}$, Asa Ibnu Hazmy ${ }^{3}$ \\ Program Studi Teknik Industri, Fakultas Teknik, Universitas Indonesia \\ Kampus Baru UI Depok 16424 \\ Email: raisa.adila41@ui.ac.id \\ Email: danu_syaifullah@yahoo.co.id \\ Email: asa.ibnu@ui.ac.id
}

\begin{abstract}
ABSTRAK
Perkembangan teknologi yang semakin besar dan pemakaian smartphone yang meningkat saat ini menjadi peluang bagi organisasi untuk dimanfaatkan dalam dunia pembelajaran. Learning Management System hadir untuk membantu guru dan murid dapat berinteraksi secara real-time dan kebanyakan LMS berbentuk website. Evaluasi usability LMS berbasis smartphone dibutuhkan agar pengguna dapat menggunakan dengan mudah. Penelitian ini bertujuan untuk mendapatkan evaluasi usability LMS berbasis smartphone dengan kriteria efisiensi, efektivitas, satisfaction, dan eror sehingga diketahui faktor apa saja yang harus diperbaiki. Evaluasi dilakukan dengan memberikan skenario task sesuai dengan fitur yang ada di LMS Ruangguru, Quipper, dan Zenius. Metode yang digunakan meliputi performance measurement, Single Ease Question (SEQ), kuesioner System Usability Scale (SUS), dan Post-Study System Usability Questionnaire (PSSUQ). Berdasarkan hasil penelitian secara keseluruhan, Zenius dan Ruangguru mempunyai nilai akhir SUS dan PSSUQ yang lebih tinggi dari Quipper. Pada kriteria efisiensi, responden lebih cepat menyelesaikan task dengan Zenius daripada Ruangguru dan Quipper. Tingkat kesuksesan Ruangguru dan Zenius lebih tinggi dari Quipper. Nilai lostness dan eror yang dihasilkan di Zenius lebih kecil daripada Ruangguru dan Quipper. Hasil penelitian ini adalah evaluasi dan komparasi usability yang dapat digunakan sebagai acuan perbaikan di masa yang akan datang.
\end{abstract}

Kata kunci: Usability; Learning Management System; Performance measurement; SEQ; SUS

\section{ABSTRACT}

The development of technology and the increasing use of smartphones are now an opportunity for organizations to be utilized in the learning world. Learning Management System is present to help teachers and students interact in real-time and most LMS is a website. Usability evaluation of LMS based smartphone is required to help users use easily. This study aims to obtain evaluation of the usability of learning management system based smartphone with the criteria of efficiency, effectiveness, satisfaction, and error so it is known what factors should be improved. Evaluation is done by providing task scenarios according to the features in LMS (Ruangguru, Quipper, and Zenius). The methods used include performance measurement, Single Ease Question (SEQ), System Usability Scale (SUS), and Post Study System Usability Questionnaire (PSSUQ). Based on the results of the overall research, Zenius and Ruangguru have higher SUS and PSSUQ's scores than Quipper. On efficiency criteria, respondents more quickly completed tasks with Zenius than Ruangguru and Quipper. Ruangguru and Zenius's success rate is higher than Quipper. Lostness and number of error in Zenius is smaller than Ruangguru and Quipper. The results of this study are the evaluation and comparison of usability that can be used as reference future improvements.

Keywords: Usability; Learning Management System; Performance measurement; SEQ; SUS

\section{Pendahuluan}

Pendidikan merupakan hal yang penting bagi setiap individu. Di Indonesia, semua penduduk wajib mengikuti program wajib belajar pendidikan dasar selama sembilan tahun. Menurut laporan Program Penilaian Siswa Internasional (PISA) 2015 yaitu program yang mengurutkan kualitas sistem pendidikan di 72 negara, Indonesia menduduki peringkat 62. Pendidikan di Indonesia masih memiliki beberapa kendala yang berkaitan 
dengan mutu pendidikan diantaranya adalah keterbatasan akses pada pendidikan, jumlah guru yang belum merata, serta kualitas guru itu sendiri dinilai masih kurang.

Menurut hasil survey yang dilakukan Teknopreneur dan APJII (Asosiasi Penyelenggara Jasa Internet Indonesia) pada tahun 2017 [1], jumlah pengguna internet mencapai 143,46 juta jiwa atau setara dengan $54,68 \%$ dari jumlah penduduk Indonesia. Dengan meningkatnya pengguna internet di Indonesia, internet mempunyai potensial yang besar untuk dimanfaatkan bagi kepentingan pendidikan dan pembelajaran. Salah satu sarana yang dapat digunakan untuk pendidikan dan pembelajaran melalui internet, ialah Learning Management System (LMS). LMS menyediakan alat yang dapat digunakan untuk mengelola kegiatan belajar mengajar dan mengintegrasikan layanan pembelajaran untuk memudahkan prosedur pengajaran dan pembelajaran [2].

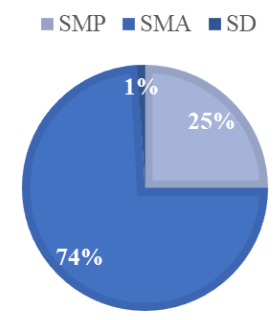

Gambar 1. Grafik pengguna Learning Management System

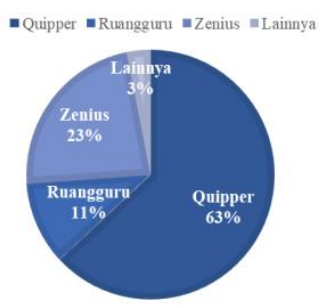

Gambar 2. Grafik Learning Management System yang digunakan

Berdasarkan hasil studi pendahuluan, Learning Management System untuk siswa yang banyak digunakan di Indonesia adalah Quipper.com, Zenius.net, dan Ruangguru.com. Pengguna Learning Management System terbanyak berasal dari kalangan siswa SMA. Oleh karena itu, pada penelitian ini akan menggunakan siswa SMA sebagai responden. Di ketiga LMS tersebut terdapat fitur yang sama, yaitu belajar mandiri di website dengan menonton video pembahasan atau materi, mengerjakan kuis dan latihan soal serta mengunduh catatan materi atau rangkuman. Media yang digunakan pada penelitian ini adalah smartphone karena fitur yang sama di ketiga Learning Management System dapat diakses di smartphone atau aplikasi.

Pada kompetisi global saat ini website merupakan komponen kunci untuk kelangsungan hidup organisasi [3]. Oleh karena itu, evaluasi usability website akan selalu dibutuhkan [4], karena akan selalu ada sesuatu yang perlu diperbaiki untuk memudahkan pengguna [5]. Usability merupakan salah satu karakteristik yang paling penting dari setiap interface dan mengukur seberapa mudah interface dapat digunakan [6]. Melalui penelitian ini diharapkan akan diketahui evaluasi dan komparasi usability dari ketiga Learning Management System di Indonesia, yaitu Ruangguru, Zenius, dan Quipper. Hasil dari penelitian ini kemudian dapat digunakan oleh Learning Management System yang diteliti, maupun Learning Management System lainnya sebagai acuan untuk perbaikan di masa yang akan dating. 


\section{Metode Penelitian}

Secara garis besar metodologi dalam penelitian ini terdiri dari lima tahap utama yang tertera pada gambar 3 .

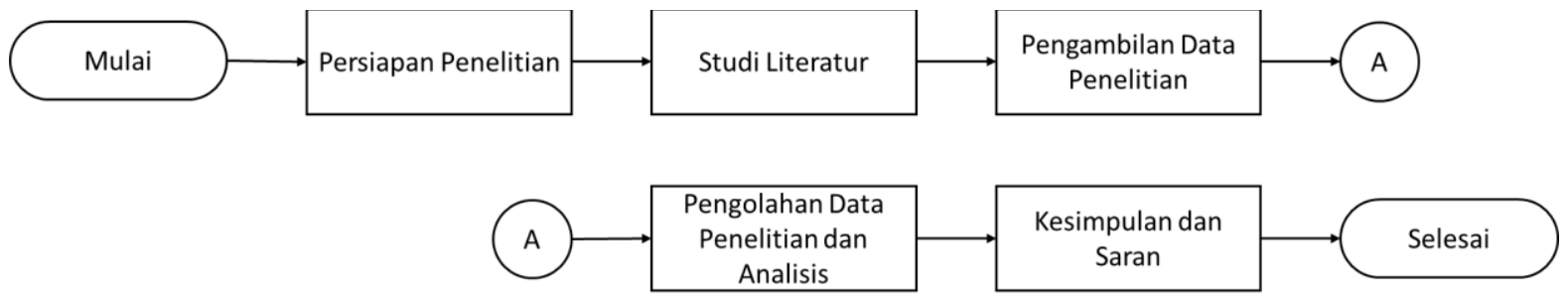

Gambar 3. Diagram air penelitian

\subsection{Objek Penelitian}

Objek pada penelitian ini adalah usability tiga Learning Management System, yaitu Ruangguru, Quipper, dan Zenius. Dalam penelitian ini, kriteria usability yang diukur adalah efektivitas, efisiensi, eror, dan satisfaction. Usability diukur dengan cara kuantitatif dan kualitatif. Pengambilan data kuantitatif diambil dengan cara melakukan usability testing yang terdiri dari beberapa skenario untuk menilai kriteria efektivitas, efisiensi, dan eror. Pengambilan data kualitatif diambil dengan menggunakan kuesioner untuk menilai kriteria satisfaction.

\subsection{Responden Penelitian}

Penelitian ini akan menguji 50 orang pengguna. Responden diminta untuk mengerjakan tugas yang sama pada ketiga Learning Management System yang berbeda. Responden akan diminta mengisi data diri dan demografi seperti nama, jenjang pendidikan, usia, jenis kelamin dan pengalaman menggunakan LMS

\subsection{Prosedur Penelitian}

Dalam penelitian ini, teknik performance measurement dapat mengukur efektivitas, efisiensi, dan eror. Kriteria satisfaction diukur menggunakan kuesioner. Urutan pengerjaan pada ketiga Learning Management System akan dilakukan secara acak. Adapun tugas yang diberikan untuk setiap Learning Management System yang diujikan adalah sebagai berikut:

\section{1. $\quad$ Log In \\ Responden akan melakukan Log in dengan Email dan Password yang sudah ditentukan sampai berhasil masuk ke тепи Home \\ 2. Fitur Berlangganan \\ Responden akan mencari harga fitur berlangganan dan menyebutkan berapa biaya untuk waktu tertentu atau fitur berlangganan apa yang sedang digunakan dan berapa lama waktu berlangganan yang dipakai \\ 3. Pemutaran Video Materi \\ Responden akan mencari pelajaran tertentu dan memutar video materi \\ 4. Pengunduhan Soal/Rangkuman \\ Responden akan mencari pelajaran tertentu dan mengunduh Soal/Rangkuman dari pelajaran tersebut}

5. Membuka Kuis

Responden akan mencari pelajaran tertentu dan membuka fitur kuis

Data yang diperoleh merupakan data task on time, data SEQ, data SUS, dan data PSSUQ. Pada bagian berikut data yang diperoleh akan dikumpulkan untuk pengolahan dan analisis.

\subsection{Pengumpulan dan Pengolahan Data \\ 2.4.1. Efisiensi}

Kriteria efisiensi dapat diukur dengan menghitung time-on-task. Time-on-Task didapatkan dengan menghitung waktu yang dibutuhkan untuk menyelesaikan skenario. Waktu yang dibutuhkan untuk menyelesaikan skenario dapat dihitung dengan cara mengurangkan waktu akhir dengan waktu mulai.

\subsubsection{Task Success Rate}

Pada penelitian ini dihitung waktu baku sebagai acuan untuk task success rate. Untuk menghitung waktu baku dibutuhkan enam responden dengan melakukan lima kali observasi dari setiap task. Setelah itu didapatkan waktu baku dengan sudah ditambahkan dengan nilai kelonggaran. Task success rate dihitung dengan memasukkan nilai "1" untuk responden yang dapat menyelesaikan tugas dalam standar waktu yang telah ditetapkan dan nilai " 0 " jika responden tidak dapat menyelesaikan tugas atau melebihi standar waktu yang telah ditetapkan. Keefektifan ini dilihat dari keberhasilan responden dalam menyelesaikan tugas. 
Lostness mengukur seberapa efektif produk atau jasa melalui usability testing. Lostness akan memberitahu apakah responden mengalami kehilangan ketika menggunakan produk atau saat usability testing. Metrik ini berkisar dari nol sampai 1. Semakin tinggi skor lostness berarti responden kesulitan menemukan apa yang responden inginkan. Skor yang rendah berarti responden menemukan apa yang mereka inginkan dengan mudah. Skor yang berada dibawah 0,4 menunjukkan bahwa tidak ada lostness dan apa pun yang berakhir menunjukkan bahwa responden merasa tersesat.

\subsubsection{Eror}

Eror merupakan kesalahan yang dilakukan dalam sub-proses pengerjaan tugas. Pengolahan data eror dilakukan dengan mengakumulasi jumlah eror yang dilakukan oleh responden di setiap task dan setiap LMS. Jumlah akumulasi eror yang terjadi di setiap tugas dibandingkan per LMS untuk mengetahui kejadian eror paling banyak.

\subsubsection{System Usability Scale (SUS)}

Kuesioner yang digunakan adalah System Usability Scale. Hasil dari penilaian dengan SUS ini adalah berupa angka tunggal dengan hasil angka mulai dari 0 hingga 100. Pada setiap poin pertanyaan, terdapat 7 skala penilaian dari 1 hingga 7 (1 untuk paling rendah, 7 paling tinggi). Kuesioner ini diberikan sebagai post-test questionnaire yang berfungi untuk melengkapi data yang berasal dari pendapat subjektif responden. Kuesioner SUS ini digunakan untuk menilai setiap LMS pada Ruangguru, Quipper, dan Zenius setelah responden melaksanakan tugas yang telah diberikan. Kemudian nilai SUS dari tiap Learning Mangement System akan dirata-ratakan untuk mendapatkan nilai akhir SUS. Berikut nilai akhir dari SUS untuk setiap Learning Management System.

\subsubsection{PSSUQ}

Data kuesioner PSSUQ diolah dengan menilai rata-rata dan melakukan uji signifikansi penilaian untuk mengetahui adanya signifikansi perbedaan tingkat kesulitan responden. Pengolahan data pengujian data dibagi ke dalam empat bagian kuesioner, yaitu Overall, System Usefulness, Information Quality, dan Interface Quality.

\subsubsection{Single Ease Question (SEQ)}

Pada bagian ini akan ditampilkan pengolahan data penilaian tingkat kesulitasn skenario Task dari ketiga LMS. Data kuesioner SEQ diolah dengan menilai rata-rata dan melakukan uji signifikansi penilaian untuk mengetahui adanya signifikansi perbedaan tingkat kesulitan responden. Pengolahan data pengujian data dibagi ke dalam lima task yang dilakukan oleh responden.

\section{Hasil dan Pembahasan}

\subsection{Analisis Data Pada Keseluruhan Aplikasi}

\subsubsection{Efisiensi}

Berikut gambar 3 menunjukkan perbandingan rata-rata time-on-task dari setiap LMS.

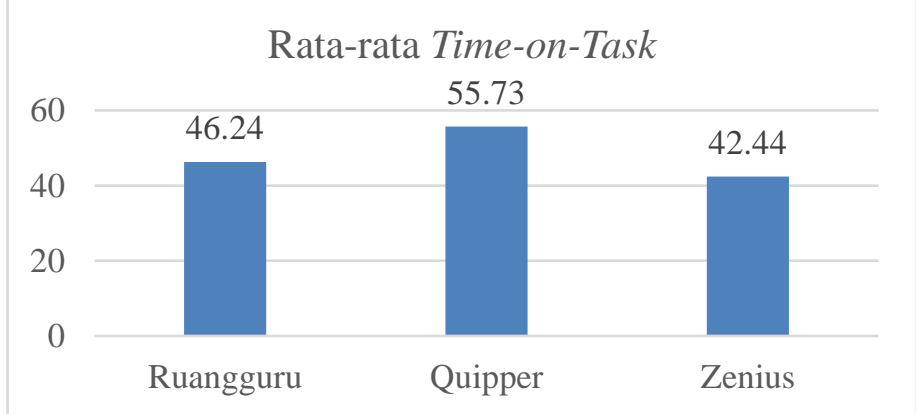

Gambar 4. Grafik perbandingan rata-rata time-on-task

Pada gambar grafik tersebut dapat terlihat bahwa waktu yang dibutuhkan menyelesaikan keseluruhan skenario Task pada ketiga LMS cukup berbeda. Waktu yang dibutuhkan untuk melakukan seluruh skenario Task pada LMS Zenius lebih sedikit yaitu 42,44 detik, setelah itu disusul oleh LMS Ruangguru selama 46,24 detik dan LMS Quipper selama 55,73 detik. Hal tersebut menunjukkan bahwa responden lebih cepat melakukan skenario task dengan LMS Zenius dibandingkan dengan LMS Ruangguru dan LMS Quipper. 


\subsubsection{Efektivitas}

Gambar 4 merupakan hasil pengolahan data task success rate dari setiap LMS.

Rata-rata Task Success Rate Setiap LMS

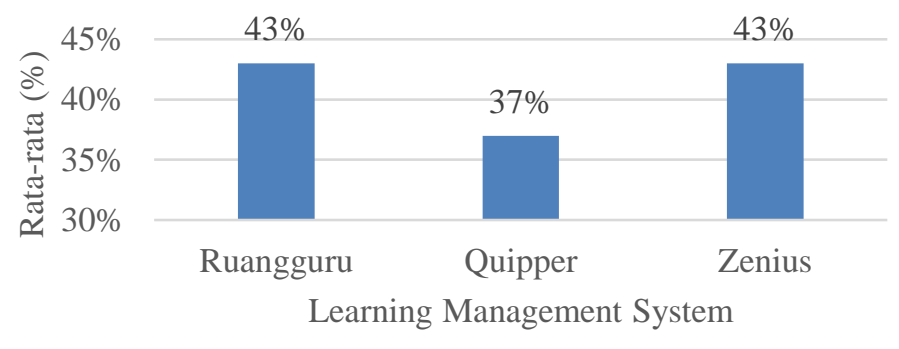

Gambar 5. Grafik perbandingan task success rate - efektivitas keseluruhan

Hasil pengolahan data menunjukkan bahwa Quipper memiliki tingkat kesuksesan paling rendah sebesar 37\%. Tingkat kesuksesan Ruangguru dan Zenius sebesar 43\%. Dari grafik diatas terlihat bahwa pada ketiga LMS memiliki rata-rata tingat kesuksesan dibawah $70 \%$. Hal tersebut menunjukkan bahwa secara kesulurahan tugas yang diujikan tergolong susah dicapai dengan waktu baku yang telah ditentukan.

Selain tingkat kesuksesan, kriteria efektivitas dapat juga diukur dengan lostness. Jika nilai lostness lebih dari 0,4 berarti responden mengalami lostness. Gambar 5 menunjukkan grafik perbandingan nilai lostness dari ketiga LMS.

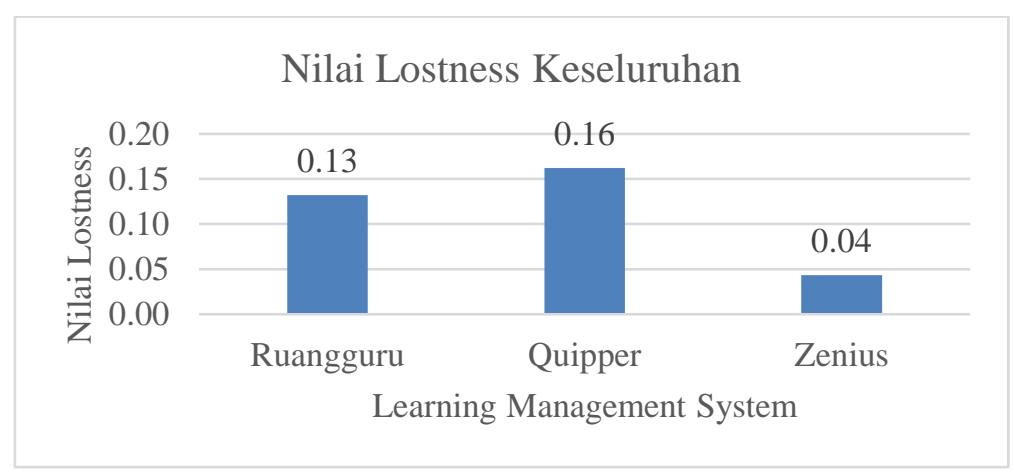

Gambar 6. Grafik perbandingan nilai lostness

Hasil pengolahan data menunjukkan bahwa Quipper memiliki nilai lostness paling tinggi sebesar 0,16 . Nilai lostness Ruangguru sebesar 0,13 dan Zenius sebesar 0,04. Dari grafik diatas dapat terlihat bahwa pada ketiga LMS memiliki nilai lostness dibawah 0,4 . Hal tersebut menunjukkan bahwa secara keseluruhan responden tidak mengalami kehilangan saat pengerjaan tugas di ketiga LMS.

\subsubsection{Eror}

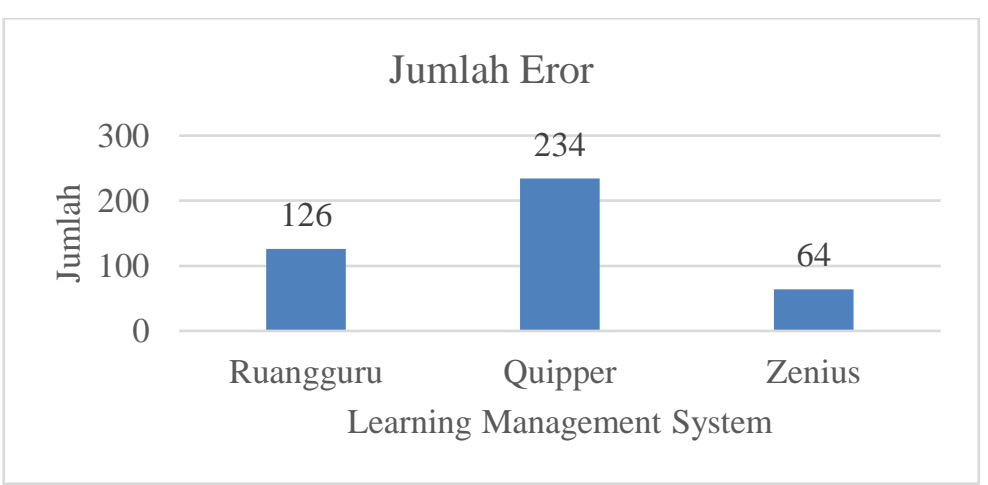

Gambar 7. Grafik perbandingan jumlah eror setiap lms 


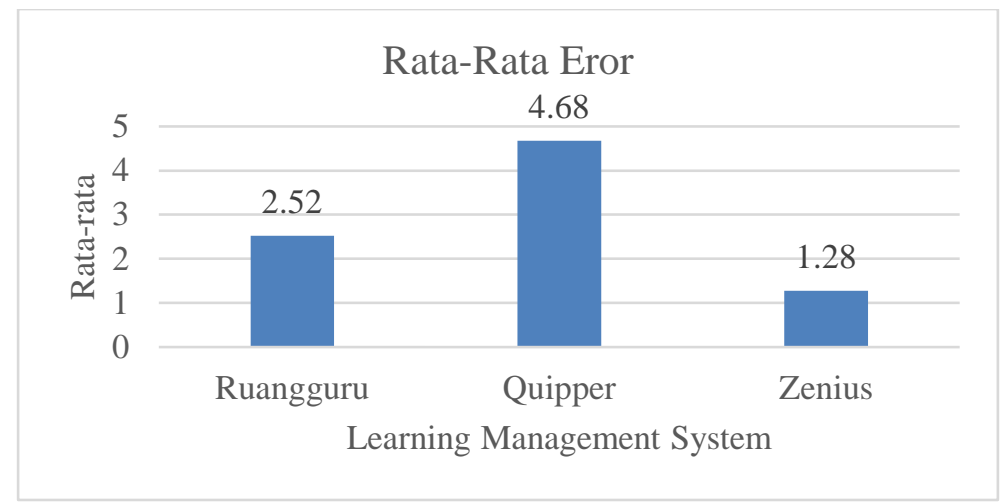

Gambar 8. Grafik Perbandingan Rata-rata Eror Setiap LMS

Pada gambar 6 dapat terlihat bahwa LMS Quipper memiliki jumlah eror terbesar dengan jumlah 234. LMS Ruangguru memiliki jumlah eror 126 dan jumlah eror terkecil adalah Zenius dengan jumlah 64. Pada gambar 7 dapat terlihat grafik perbandingan rata-rata eror dari ketiga LMS. LMS Quipper mempunyai rata-rata eror tertinggi dengan nilai 4,68 dan disusul LMS Ruangguru dengan nilai rata-rata eror 2,52. LMS Zenius mempunyai nilai rata-rata eror terkecil, yaitu 1,28. Hal ini menunjukkan bahwa eror yang dihasilkan di LMS Zenius lebih sedikit daripada LMS Ruangguru dan LMS Quipper. Eror yang sering muncul saat pengerjaan yaitu kesalahan dalam memilih fitur atau menu dalam aplikasi. Hal ini disebabkan karena letak tombol fitur/menu yang dicari tidak terlihat jelas di halaman awal dan juga penggunaan Bahasa Inggris pada aplikasi LMS Quipper.

\subsubsection{System Usability Scale (SUS)}

Kuesioner SUS ini akan diisi oleh setiap responden sehabis melakukan usability testing pada tiga Learning Management System. Adapun rata-rata nilai SUS ketiga LMS ditunjukkan pada gambar 8.

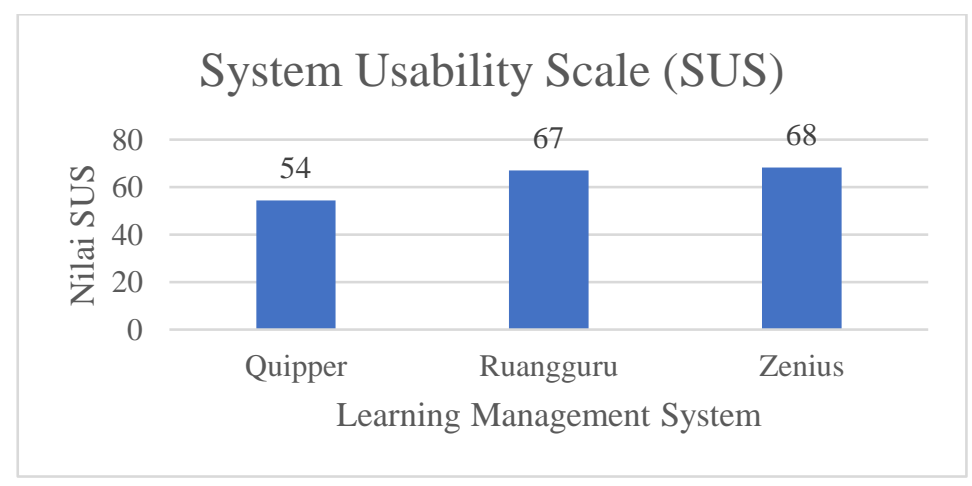

Gambar 9. Grafik perbandingan kuesioner SUS ketiga LMS

Pada grafik dapat terlihat perbedaan nilai SUS yang dimiliki pada ketiga LMS. LMS Zenius mendapatkan nilai rata-rata 68, Ruangguru mendapatkan nilai rata-rata 67, dan Quipper mendapatkan nilai 54.

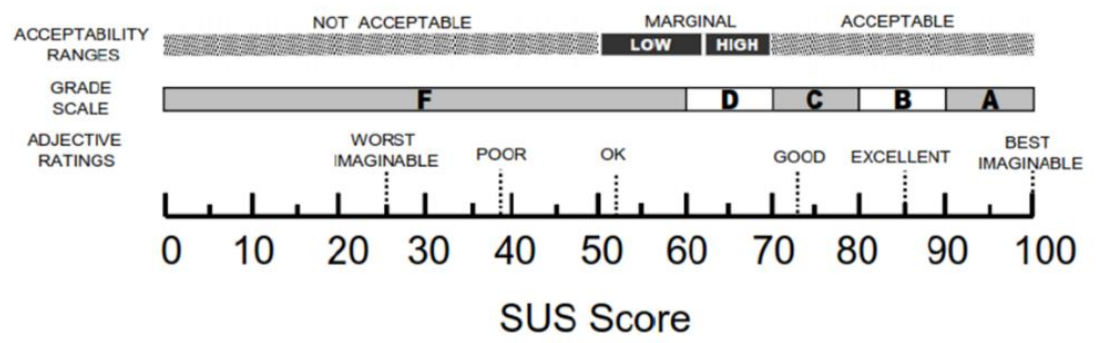

Gambar 10. Skala nilai SUS [7]

Berdasarkan skala nilai SUS pada gambar 9, Zenius dan Ruangguru masih tergolong kelas rata-rata yang tinggi atau hampir tergolong yang dapat diterima. 
Sedangkan Quipper tergolong kelas rata-rata yang rendah atau hampir tergolong tidak dapat diterima. Hasil tersebut menunjukkan bahwa Quipper mempunyai tingkat urgensi yang lebih tinggi untuk melakukan pengembangan/perbaikan karena nilai SUS yang rendah dibandingkan dengan Zenius dan Ruangguru.

\subsubsection{PSSUQ}

Hasil kuesioner PSSUQ telah dihitung rata-rata pada setiap LMS. Berikut ini adalah hasil pengolahan data PSSUQ Overall untuk setiap LMS.

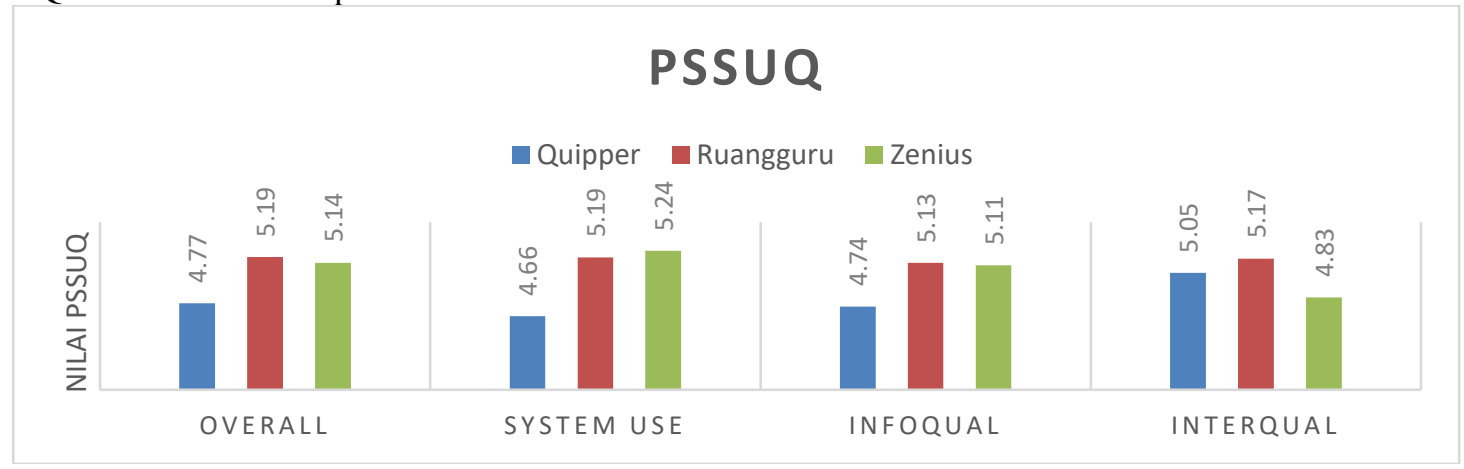

Gambar 11. Grafik perbandingan hasil PSSUQ ketiga LMS

Dapat terlihat pada gambar 10. di atas nilai PSSUQ yang dimiliki ketiga LMS cukup terlihat perbedaannya. Quipper mendapatkan nilai rata-rata 4,77, Zenius mendapatkan nilai rata-rata 5,14, dan Ruangguru mendapatkan nilai rata-rata 5,19. LMS Ruangguru menempati peringkat pertama pada bagian Information Quality dan Interface Quality, sedangkan LMS Zenius menempati peringkat pertama pada bagian System Usefullness. Hal ini menunjukkan bahwa LMS Ruanguru lebih bagus dalam hal kualitas informasi dan kualitas antar muka yang ditampilkan.

Setelah dilakukan analisis secara keseluruhan, didapatkan peringkat pada tiap kriteria usability seperti pada tabel 1.

Tabel 1. Ranking penilaian secara keseluruhan

\begin{tabular}{cccc}
\hline \multicolumn{4}{c}{ Ranking } \\
\hline Kriteria & Ruangguru & Quipper & Zenius \\
\hline Efisiensi - Time-on-Task & 2 & 3 & 1 \\
Efektivitas - Task Success Rate & 1 & 3 & 1 \\
Efektivitas - Lostness & 2 & 3 & 1 \\
Eror & 2 & 3 & 1 \\
Satisfaction - SUS & 2 & 3 & 1 \\
Satisfaction - PSSUQ & 1 & 3 & 2 \\
Total & 10 & 18 & 7 \\
\hline
\end{tabular}

Pada kriteria efisiensi, efektivitas (lostness), eror, dan satisfaction (SUS), LMS Zenius yang menempati peringkat pertama dari keseluruhan penilaian disusul oleh LMS Ruangguru dan LMS Quipper. Pada kriteria efektivitas (Task Success Rate), LMS Zenius dan LMS Ruangguru menempati peringkat yang sama, lalu disusul oleh LMS Quipper. Pada kriteria satisfaction (PSSUQ), LMS Ruangguru yang menempati peringkat pertama dari keseluruhan penilaian disusul oleh LMS Zenius dan LMS Quipper. Setelah dilakukan dari setiap kriteria, didapatkan ranking berdasarkan performance metric dan self-reported metric. Tabel 2 merupakan ranking penilaian keseluruhan berdasarkan performance metric dan self-reported metric.

Tabel 2. Ranking penilaian keseluruhan berdasarkan performance dan self-reported metric

\begin{tabular}{cccc}
\hline \multicolumn{4}{c}{ Ranking } \\
\hline Metric & Ruangguru & Quipper & Zenius \\
\hline Performance & 2 & 3 & 1 \\
Self-Reported & 1 & 3 & 1 \\
\hline Total & 3 & 6 & 2 \\
\hline
\end{tabular}


Pada performance metric, LMS Zenius yang menempati peringkat pertama disusul oleh LMS Ruangguru dan LMS Quipper. Pada self-reported metric, LMS Ruangguru dan Zenius menempati peringkat yang sama lalu disusul oleh LMS Quipper. Setelah didapatkan seluruh penilaian, LMS Zenius merupakan LMS dengan penilaian usability yang paling unggul dari segi performance metric dan self-reported metric daripada LMS Ruangguru dan LMS Quipper.

\section{Kesimpulan dan Saran}

Penelitian ini memiliki tujuan untuk mendapatkan evaluasi usability dari tiga Learning Management System berbasis smartphone dengan kriteria efisiensi, efektivitas, satisfaction, dan eror. Selanjutnya, melalui evaluasi ini dapat diketahui bagian atau kriteria apa saja yang harus diperbaiki kedepannya. Berikut ini merupakan penjelasan kesimpulan dari hasil penelitian yang telah didapat.

Penelitian ini berfokus kepada evaluasi usability Learning Management System berbasis smartphone yaitu Ruangguru, Quipper, dan Zenius. Pengujian dilakukan berdasarkan dengan kriteria usability kepada 50 responden yang terdiri dari 25 responden pria dan 25 responden wanita.

Secara keseluruhan, nilai akhir SUS dan PSSUQ Ruangguru dan Zenius lebih tinggi dari Quipper. Pada kriteria efisiensi, responden lebih cepat melakukan skenario task dengan Zenius dan Ruangguru dibandingkan dengan LMS Quipper. Tingkat kesuksesan Ruangguru dan Zenius lebih tinggi dari Quipper. Nilai lostness Zenius lebih kecil daripada Ruangguru dan Quipper. Eror yang dihasilkan di LMS Zenius lebih sedikit daripada LMS Ruangguru dan LMS Quipper.

Penelitian terkait usability dari Learning Management System merupakan penelitian yang memiliki potensi yang tinggi untuk dikembangkan karena perkembangan teknologi saat ini dan pemakaian smartphone yang meningkat. Namun, masih sedikit penelitian tentang usability dari Learning Management System berbasis smartphone. Oleh karena itu, penelitian selanjutnya diharapkan dapat meninjau dari kriteria usability lainnya sehingga faktor evaluasi semakin beragam dan dapat melakukan evaluasi ergonomi secara menyeluruh baik dari segi fisik, lingkungan, maupun kognitif. Pemilihan responden dalam penelitian dipilih yang dapat merepresentasikan seluruh target pengguna aplikasi sehingga hasil evaluasi mendapat masukan dari berbagai latar belakang responden. Penelitian selanjutnya dapat melakukan pembuatan, pengujian dan evaluasi terhadap desain aplikasi Learning Management System yang baru.

\section{Daftar Pustaka}

[1] Asosiasi Penyelenggara Jasa Internet Indonesia. (2018). Infografis Penetrasi Dan Perilaku Pengguna Internet Indonesia: Survey 2017. https://apjii.or.id/survei2017 [Diakses pada tanggal 26 Februari 2018].

[2] Albarrak, A.I., Aboalsamh, H.A., Abouzahra, M. (2010). Evaluating Learning Management Systems For University Medical Education. In: IEEE International Conference on Education and Management Technology (ICEMT 2010), Cairo: Egypt, 2-4 November 2010.

[3] Mentes, S. A., \& Turan, A. H. (2012). Assessing The Usability Of University Wesites: An Empirical Study On Namik Kemal University. The Turkish Online Journal of Educational Technology, 11(3), 61-69.

[4] Ferre, X. (2005). Integration Framework Usability In The Software Development Process. Universidad Politecnica de Madrid. Madrid: UPM. Retrieved from http://oa.upm.es/440/1/XAVIER_FERRE_GRAU.PDF.

[5] Rodríguez, G., Perez, J., Cueva S., \& Torres, R. (2017). A Framework For Improving Web Accessibility And Usability Of Open Course Ware Sites. Computers \& Education 109 (2017) 197-21. http://dx.doi.org/10.1016/j.compedu.2017.02.013 .

[6] Nielsen, J. (2012). Usability 101: Introduction to Usability. [online] Nielsen Norman Group. Available at: https://www.nngroup.com/articles/usability-101-introduction-to-usability/ [Diakses pada tanggal 23 Januari 2018].

[7] Bangor, A., Kortum, P., \& Miller, J. (2009). Determining What Individual SUS Scores Mean - Adding Adjective Rating Scale. Journal of Usability Studies, 114-123. 